\title{
A Financial Model for Economic Analysis of Cement Factory
}

\author{
Bijan Bidabad ${ }^{1} \quad$ Mahshid Sherafati ${ }^{2} \quad$ Rohollah Mohammadi ${ }^{3}$
}

\begin{abstract}
In this paper, a method is presented to combine financial data and financial statements for economic analysis, which consequently introduces a software application for determining the economic structure of a cement factory. This software converts nearly 300 items of raw data of a cement factory to almost 4 times more economic-analytic information. The software analyzes the quantity and quality of production activities in addition to the cost structure of the concerned cement factory. It provides more than 80 descriptive figures, which have been defined previously and are applied to illustrate the economic structure of the cement factory. The calculated tables and figures are able to guide decision makers of the cement factory with regard to inefficiencies, obstacles, and various problems in the factory. In the end, a set of policies for increasing production efficiency and reducing costs are expressed briefly, which can be considered as the primary plans to operationalize the analytical information of the software. It is worth to mention that the presented structure of the software has been designed for Abyek Cement Factory. However, it can be employed as a guiding project for other cement factories as well. In other words, the software can be rebuilt with consideration of their specific information by revising and adjusting the software structure to cover their specific features.
\end{abstract}

\section{Keywords: Financial Software, Cement Economics, Financial Analysis, Cement Factory, Abyek Cement Factory, Efficiency}

\section{Introduction}

There are often particular disagreements among accountants and economists with respect to the common definitions and concepts in both fields. These differences have prevented both groups from benefiting from the findings of one another. In order to develop common analytical concepts, a set of information containing about 300 items was collected. These items are mostly published in financial reports and statements of any cement factory. Afterward, by adding other supportive information, benchmarks, and several mathematic formulas, the number of items was extended into about 1,000 and used by Fars \& Khuzestan Cement Company (FKCCO), which is called the Analytical Information Software for Abyek Cement Factory. Considering the significant similarities of cement factories in terms of their economic structure, this set of information can be employed by other analysts in similar cement companies. Undoubtedly, the software structure of these pieces of information should be adjusted to the particular specifications of companies. However, it can be stated that the analysis can be generalized to similar cement factories.

Most often, the presented views are provided along with economic insights. Hence, it can be said that the definitions and concepts of financial statements have been converted into economic concepts. The available analyses show the past and present trends from an economic perspective, and they do not seek the reasons other than the issues related to economic subjects. This software can depict the economic perception of a cement company. The Cement Analytical Information Software was designed with the aid of Excel software with the following features.

I (B.A., M.Sc., Ph.D., Post-Doc.) Professor of Economics and economic advisor to.Fars \& Khuzestan Cement Company (FKCCo). Site: http://www.bidabad.com, Email: bijan@bidabad.com,

This paper is a summary of some parts of the research project: "Studying the economic structure of Abyek Cement Factory", Fars \& Khuzestan Cement Company (FKCCo), Bijan Bidabad. (Revised) Presented at International Conference on Business Strategy and Social Sciences (ICBSSS), Asian Economic and Social Society (AESS), Faculty of Technology Management and Business, Universiti Tun Hussein Onn Malaysia, and Pak Publishing Group. 16-I7 August 20I4, Kuala Lumpur, Malaysia.

${ }^{2}$ MBA Department, Management Faculty, Multimedia University, Malaysia. mahshidsherafati@yahoo.com

${ }^{3} \mathrm{CEO}$ at Novin-Pazhouhan Research and Engineering Company, Tehran, Iran. http://www.imif.ir/ Rmohamadi58@gmail.com 


\section{Main Parts of Information}

The main parts of information in the Cement Analytical Information Software consist of the following topics:

Part I. Quantitative production: Including production of all types of cement such as regular, pozzolan, and PKZ cement, and their shares from the total amount of production.

Part 2. Cement and clinker inventory: The inventory at the beginning and end of the period for all types of cement and clinker, the ratios of inventory at the end of the period to the total amount of production, and cement and clinker production and their net inventory, various ratios between cement and clinker.

Part 3. Quantitative sales: Selling all types of cement in bulk or bag, selling the exported clinker, bags, and local consumption of cement. Some controllers are brought here to compare the sales and production volume, and the inventories at the beginning and end of the period.

Part 4. Rial sales (i.e., the money value of sales): Including sales of all types of cement and clinker according to the current status of different packaging, subsidies, and discounts.

Part 5. Selling price: Including the price of all types of cement and clinker, which is implicitly obtained by dividing the Rial sales by quantitative sales.

Part 6. Bags: Including production, Rial sales, number of bag sales, and the consumption of bags containing cement.

Part 7. Cost of packaging materials: Including the cost of bags and sacks, and packaging raw materials.

Part 8. Consumption of packaging materials: Including graphite paper, glue, ink, alcohol, and cost of each bag and its raw material.

Part 9. Mineral raw materials: Including the consumption level of limestone, soil, gypsum, iron ore, pozzolan, and the percentages of consuming mineral raw materials in the production of clinker and cement.

Part I0. Price of raw materials: Including the price of limestone, soil, gypsum, iron ore, and pozzolan per ton.

Part I I. Production factors of electricity and fuel: Including consuming electricity and fuel based on the gas and fuel oil per calorie and their unit price, and also per each ton of cement and clinker production.

Part 12. Personnel's academic degrees: Including the number of personnel with the degrees of bachelor and higher, upper diploma, diploma, under diploma, and illiterate.

Part 13. Personnel's service location: Including production centers, production support centers, and the centers for general services, and administrative, financial, and commercial affairs.

Part 14. Production factor of working: Including working hours and overtime working hours during the year, the average monthly salary of production and non-production personnel, average monthly working and overtime working hours of personnel, the average wage per each hour, and the efficiency ratio of the workforce.

Part I5. Abrasive materials: Including ball, segment, and armor and price of abrasive materials and their consumption level per a ton of cement and clinker production.

Part 16. Stoppage working hours: Based on the grinders of raw materials and cement, and furnaces.

Part 17. The annual capacity of working hours: Based on the grinders of raw materials and cement, and furnaces.

Part I8. Percent of using working capacity: Based on the grinders of raw materials and cement, and furnaces.

Part 19. Available capacity: Based on the grinders of raw materials and cement, and furnaces, and also according to the percentage of using total production capacity, and amount of not-produced, and the lost profit due to not making use of total production capacity.

Part 20. Cash and bank capital stocks: Including balances of bank accounts, cheques in the process to be cleared, clearing papers, gold and coins, foreign currencies, cash in transit, and cash on hand.

Part 2I. Commercial accounts and bills receivable: Including main items of commercial operation of the company including commercial accounts and bills receivable. Liabilities of the subsidiary and affiliated companies appear under this account. 
Part 22. Other accounts and bills receivable: Including main financial items, out of company operations.

Part 23. Inventory of materials and goods: Including finished products, products in process, raw materials, spare parts, building materials, refractory materials, consignment, and other inventories of materials and goods stored in warehouses.

Part 24. Orders of materials and goods: Including raw materials and spare parts, which have already been ordered, but not yet entered in the warehouse.

Part 25. Prepayments: Including prepayments for internal purchases of spare parts and raw materials, services, and other advance payments.

Part 26. Added assets: Including land, building, machinery and equipment, tools, molds, automobiles, furniture, installations, and assets in the process of completion, prepayments, inventories, capital orders, and other items.

Part 27. Sold assets: Including sell of land, building, machinery and equipment, tools, molds, automobiles, furniture, installations, and assets in the process of completion, and other capital assets.

Part 28. Adjustments and transfer of assets: Including adjusting errors from past years to the current year, and transferring assets as added or sold assets.

Part 29. Other assets: Including a portion of long-term claims and transfer costs to future years, trusts, patents, deposits, and other assets' items.

Part 30. Commercial accounts and bills payable: Including commercial accounts and bills payable. Debts to subsidiary and affiliated companies are booked in this account.

Part 3I. Insurance and taxes payable: Including insurance and withholding taxes payable.

Part 32. Other accounts payable: Including overpayments and canceled sales invoices of customers, companies and institutes accounts, taxes and dues, deposits payable, and other accounts payable.

Part 33. Financial loans receivable: Including short and long terms of financial loans. Prepayments from customers, savings (reserves) of employees' retirement benefits and the head office current account appear under this account.

Part 34. Capital and investment: Including properties, machinery and equipment, accumulated and annual depreciation, book value of capital, financial depreciation, asset growth, machinery and equipment, capital and investment items, depreciation based on book prices, ratios of investment to depreciation and to capital stock, ratio of capital depreciation to gross capital stock, and indices based on discrepancies and mismatches of depreciation and investment accounts. Regression calculations of depreciation in this part are to achieve more actual and stable depreciation rates all are placed under the subsections of this title.

Part 35. Capital present value to prices of the same year: Including investment and net (of depreciation) and gross capital and by considering actual annual and accumulated depreciation based on present value comparing with the price of the same year. The ratios of depreciation to capital, investment to depreciation, actual depreciation to capital, production value, and profit to capital stock are the other indices of this part.

Part 36. The present value of capital to the fixed price of the last financial year: Including the present value of investment depreciation, actual depreciation, net and gross capital stock to the fixed price of the last financial year.

\section{Markup prices of sold products and services:}

Part 37. Consumed raw materials: Including paid costs for packaging materials, minerals, and other items.

Part 38. Wages and salaries for production: Including wages and salaries, overtime working, insurance, benefits, bonuses, costs for benefits of employees' retirement, and other personnel's related payments.

Part 39. Overhead costs: Personnel's wages and salaries including all personnel's payments (such as salary, wage, overtime working, bonuses, benefits, insurance, missions, etc.), abrasive materials, refractory materials, fuel, electricity, maintenance, bags and sacks, food materials, consuming oils, machinery rents, consulting fees, spare and supportive parts, depreciation, and other items, which all constitute gross overhead costs. By subtracting mine's overhead costs, portions of executive, general, distribution and sales departments, transfer to fixed assets, other costs, adjustments, and the costs due to not producing, the actual overhead cost can be obtained. The total cost of production is 
obtained by subtracting non-absorbed costs of production from actual overhead costs. This value calculates markup price of finished goods by considering the product in the process of production at the beginning of the period, the transferring inventories to subsidiary and affiliated companies, and the products in the process of production at the end of the period. The mentioned value provides markup price of finished goods (ready for sale), by considering finished goods at the beginning of period, transferring inventories to subsidiary and affiliated companies, consumption of finished goods, and production wastes and regarding the finished goods at the end of the period, the markup price of the sold goods is obtained.

Part 40. Administrative and general costs: Including employees' wages, salaries, and benefits, water, electricity, fuel, gas, consuming goods, repair and maintenance, depreciation, the share of services costs, management fees of head office and other items. The mentioned items by considering the transferring costs to other departments, selling of agricultural products, and transferring to subordinates and superiors, constitute the overall administrative and general costs.

Part 4I. Distribution and sales costs: Including personnel's wages, salaries, and benefits, the share of distribution and sales cost from service costs, other items, and adjustments.

Part 42. Other revenues and costs: Including profit resulting from selling properties, machinery, equipment, interests of bank deposits, profit from selling wastes, salvage, and unused items, other net revenues and costs, and financial and unabsorbed costs.

Part 43. Profit (loss): Including calculations of operational and net profit (loss), the ratio of profit (loss) to Rial and quantitative sales of cement, ratios of profit elements including sales, total costs of sold goods, administrative, general and distribution costs, sales revenues and other costs.

Part 44. Contra accounts: Including guaranteed documents of the company, in the hands of others and vice versa, and other documents.

\section{Calculation of short-term costs:}

Part 45. Short-term actual cost: Including salaries, mineral raw materials, packing materials, fuel, electricity, depreciation, abrasive materials, refractory materials, oil, other items, and their shares.

Part 46. Accounting of a ton of cement produced (short-term): Including selling price of a ton of cement produced, profit (loss), and cost of a ton of cement produced in the short term according to the cost items, the share of cost items, and the profit out of sales.

Part 47. Short-term actual cost with actual depreciation: Including calculation of short-term cost based on different elements and by considering actual depreciation (not booked depreciation) and share of short-term cost items.

Part 48. Accounting of a ton of cement produced with actual depreciation: Including short-term sales and profit (loss) and short-term cost of each ton of cement produced based on its components and their shares.

Part 49. Accounting of a ton of cement produced with actual depreciation (exponential fitness): Including fitted information by exponential regressions, in order to find the past and future trends of sales, profit, and costs of its components in short time, and their shares.

\section{Calculation of long-term costs:}

Part 50. Total long-term costs: Including wages, mineral raw materials, packing materials, fuel, electricity, depreciation (mineral, abrasive, refractory materials, and oil), and other items, increase of properties, machinery, equipment, and their shares from the long-term costs.

Part 5I. Accounting of a ton of cement produced (long-term): Including selling price of each ton of cement produced, profit (loss) and cost of each ton of cement produced in the long term based on the cost components and percentages of cost components and profits from the sale.

Part 52. Total long-term cost with actual depreciation: Including calculation of long term cost based on different elements and by considering actual depreciation (not booked depreciation) and proportions of components of long term costs.

Part 53. Accounting of a ton of cement produced with actual depreciation (long term): Including long term sales and profit (loss), and long term cost of each ton of cement produced based on its components and their shares. 
Part 54. Accounting of each ton of cement produced with actual depreciation (exponential fitness): Including fitted information by exponential regressions in order to find the past and future trends of sales, profit, costs, and its components in the long term, and their shares.

Part 55. Production factors: Including working, mineral raw materials, packing materials, fuel, electricity, depreciation, materials (abrasive, refractory materials, and oil), other items, and gross investment.

Part 56. Price of production factors: Including prices of labor, mineral raw materials, packing materials, manufacturing, electricity, consuming materials, and the price index of depreciation cost, investment, and other items, in constant prices of the last financial year of the period.

Part 57. Ratio of production factors to production: Including working hour per ton of cement produced, ton of mineral raw materials per ton of cement produced, ton of packaging materials (number of bags) per ton of cement produced, million kcal of consumed fuel per ton of cement produced, consumed electricity per ton of cement produced, consuming materials (abrasive, refractory materials, and oil), depreciation and other items, and investments per ton of cement produced.

Part 58. Statistics of the ratios of production factors to production: Including statistics of minimum, maximum, mean, medium, and standard deviation for the ratios of work to production, mineral raw material to production, packaging materials to production, million kcal of consumed fuel to production, electricity to production, depreciation, consuming materials, other items, and gross investment in constant prices to production.

Part 59. Short-term efficient production function based on the minimum ratios of production factors to production: Including optimal production based on the minimum ratios of short-term production factors to production, the difference between practical and optimal production, and inefficiency percentage of production. The efficient production function has been written based on the production factors of work, mineral raw materials, fuel, electricity, and consuming materials.

Part 60. Optimal need for production factors in the short term: Including the optimal need to work, mineral raw materials, million kcal of fuel, electricity, and consuming materials, which should be used in optimal production conditions.

Part 6I. Difference between practical consumption and optimal need of production factors in the short term: Including the excess amount of usage of work, raw materials, fuel, electricity, and consuming materials more than the optimal amount.

Part 62. Percentage of inefficient use of production factors: Percentage of the difference between optimal need and practical use of production factors in the short term compared with all applied production factors.

Part 63. Cost of additional use of production factors in the short term: Including the costs lost because of excess use of production factors. The percentage of these costs to the costs of production factors has appeared as indices of inefficiency.

Part 64. Costs of inefficient production in the short term: Including the lost opportunity cost of selling cement due to nonoptimal production, cost of inefficient use of production factors in the short term, lost profit because of not using the remained production capacity, and the total costs of inefficient production in the short term. The ratios of inefficient production costs to profit, production, net and gross capital stock are of the other items in this section.

Part 65. Costs of deferred purchase: This is used as an estimation to find the costs of the slowness of activities for purchasing raw materials, other items, net purchase and sale of properties, for one, one and a half, and two months delays in purchasing, and the role of such delays as the share of profit.

Part 66. Price index: Various price indices have been applied for evaluation. All their base years are the last year of the period in order to have consistencies with the figures of this group. This section includes the price indices of consumer, wholesale, wages and salaries, private capital formation index, the price index of cement, fuel, fuel oil, calorie fuel, abrasive and refractory materials, oil, gas, and their growth rate.

Part 67. The basis for calculating price indices: Including the calculation components of wholesale, retail and investment price indices, based on existing base years and converting them into base financial year and foreign exchange rate in the unofficial market. 


\section{Structure of Cement Analytical Information Software}

There exists a very large amount of performed calculations in the Cement Analytical Information software. To clarify more indepth, for Abyek Cement Factory, approximately 20,000 computational cells containing numbers, statistics, and formulas are responsible for the numerical arrangement of information. Nearly 85 various diagrams have been defined relating to these cells, illustrating the trends of quantitative data. In the following table, the column on the left indicates the row number in the software, and the next column shows the subject name in the software. Due to a large number of mathematical formulas and detailed items, they have not been provided in this section.

\section{Row The header of the chapter in the software}

5 Quantitative production

I8 Cement and clinker inventory (quantity)

38 Sales (quantitative)

59 Sales (Rial)

$76 \quad$ Selling price

88 Bag

97 Cost of packaging materials

I05 Consumption of packaging materials

II5 Consumption of mineral raw materials

I37 Price of consuming raw materials

I45 Production factors for electricity and fuel

I69 Personnel's educational degrees

I77 Personnel's service location

I83 Labor production factor

201 Abrasive materials

2 I3 Refractory materials

225 Non-production hours in a year

234 Working hours capacity in year

242 Percentage of using working capacity

254 Available capacity

272 Cash in hand and in bank

$28 \mathrm{I}$ Accounts and bills receivable

290 Other accounts and bills receivable

298 Materials and goods inventories

310 Orders of materials and goods 
Row The header of the chapter in the software

317 Prepayments

$331 \quad$ Added assets

345 Sold assets

359 Adjustments and transfer of assets

373 Other assets

380 Accounts and bills payable

387 Insurance and taxes payable

394 Other accounts and bills payable

403 Financial loans receivable

4I4 Capital, investment, and depreciation

428 Regression calculations of depreciation

448 The present value of capital at constant prices of the same year

465 The present value of capital at constant prices of 1997-1998

474 Markup price of sold goods and services

475 Consumed raw materials

485 Salaries and wages for production

495 Overhead costs

499 Personnel's salary and wage

555 Administrative and general costs

574 Sales and distribution costs

579 Other revenues and costs

$588 \quad$ Profit (loss)

610 Contra accounts

616 Short-term cost calculation

617 Short-term actual costs

638 Accounting of a ton of cement produced (short-term)

663 Short-term actual cost with actual depreciation

684 Accounting of a ton of cement produced with actual depreciation (short-term)

709 Accounting of a ton of cement produced with actual depreciation (exponential fitness) 


\section{Row The header of the chapter in the software}

735 Long-term cost calculations

736 Long-term actual costs

759 Accounting of a ton of cement produced (long-term)

786 Long-term actual cost with actual depreciation

809 Accounting of a ton of cement produced with actual depreciation (long-term)

836 Accounting of a ton of cement produced with actual depreciation (exponential fitness)

864 The set of production factors

875 Price of the set of production factors

886 Ratios of production factors to production

897 Statistics of ratios of production factors to production

908 Short-term efficient production function with minimum factors to production ratios

913 Optimal need for production factors in the short term

920 The difference in optimal need and practical consumption of production factors in the short term

927 Percentage of inefficient use of production factors

934 Cost of excess use of production factors in the short term more than optimal usage

949 Cost of production inefficiency in the short term

960 Cost of deferred purchase

979 Price index

\section{Economic Investigation of Cement Factory}

Explanations and analyses of this part are primarily based on the Cement Analytical Information Software. In order to simply become well-aware of the general state of a cement factory, some diagrams have been designed in Cement Analytical Information Software showing the events occurred during the study period. They are mostly clear and do not require further explanation. In general, the diagrams and tables analyze and study the following topics:

Topic I. Actual depreciation and losses

Topic 2. Capital rate of return

Topic 3. Inefficiency of production

Topic 4. Planning for production and sales

Topic 5. The current value of the cement factory

Topic 6. The general trend of developments and changes

Topic 7. Price of production factors

Topic 8. Cost components

Topic 9. Salary and wage

Topic I0. Cement price

Topic II. Personnel of different departments

Topic I2. Slowness of workflow

Topic I3. Insufficiency of information 
The purpose of this part is not to provide detailed recommendations with regard to the operational components of a cement factory. It has been tried to only obtain a general overview of fundamental issues. Basically, the issues can be categorized into two divisions of policymaking, i.e., cost reduction and increasing efficiency. The other important policies in this subject are: revising management information structure, increasing workflow speed, and planning to reach nominal production capacity. The figures and their short descriptions are as follow:

Graph I. It shows the production trend of cement and clinker.

Graph 2. It seeks to find the proportion of cement to clinker. In order to find this ratio, clinker production is added to inventory at the beginning of the period. Then, the inventory at the end of the period and the number of clinker exports are deducted from that. Finally, this figure is divided by cement production quantity.

Graph 3. It presents the share of production of different types of cement in the factory in different years.

Graph 4. It shows the cement and clinker inventory in the beginning and end of the period.

Graph 5. It reflects the ratio of inventory at the end of the period to total cement and clinker production.

Graph 6. It compares the amount of production plus a net inventory of cement and clinker, with cement sales.

Graph 7. Logically, sales must be equal to the amount of production plus net inventory. The difference between these two figures in the cement factory would represent the amount of unsold cement, which has been consumed internally.

Graph 8. The amount of the aforementioned difference per ton is illustrated in this figure.

Graph 9. It shows the Rial difference of the above-mentioned difference.

Graph I0. It displays the cement sales in bag and bulk in the concerned period per ton.

Graph II. This figure presents the above figure, but in Rial.

Graph 12. It exhibits the share of selling different types of cement to total sales of each year per ton.

Graph I3. It indicates the percentage of sales of different types of cement to total sales of each year per Rial.

Graph I4. It shows the increasing trend of cement price during the study period.

Graph I5. It compares the wholesale price indices of goods and services with the cement price index.

Graph 16. It reflects the percentage of raw materials in one cement unit. The amount of consuming raw materials has usually $60 \%$ waste in production.

Graph 17. It shows the percentage of raw materials in each clinker unit. In other words, in order to have a more precise investigation of the ratio of used raw materials for production of each clinker unit, the amounts of used iron ore, limestone, and soil can be observed. In this figure, it can be witnessed that what percentages of each of 6 initial materials are production wastes.

Graph 18. It exposes the price trend (extraction costs) of raw materials.

Graph 19. It indicates the number of personnel in the concerned period.

Graph 20. It presents the personnel's combination in terms of their education levels.

Graph 2I. It shows the trend of average monthly salaries of production, non-production, and all personnel.

Graph 22. It makes a comparison between the consumer price index and the monthly wage index of the factory. This figure confirms whether the personnel's average salary has been adjusted by price increases or not.

Graph 23. It presents the average monthly working and overtime working of personnel.

Graph 24. It indicates the average wage per hour of work.

Graph 25. It reveals the average cement and clinker production per personnel.

Graph 26. It discloses consumed electricity in different years.

Graph 27. It displays consumed calorie of fuel in different years.

Graph 28. It shows the price of fuel oil and electricity per liter and per $\mathrm{kW}$, respectively.

Graph 29. It exposes the consumed fuel price in millions of kcal.

Graph 30. It shows electricity consumption in a ton of cement and clinker production.

Graph 3I. It shows the calorie of consuming fuel per ton of production. The amounts of calories of gas and fuel oil in this figure have been calculated according to available energy (calorie) of consumed fuel oil and gas. Finally, they have been obtained in terms of a ton of cement and clinker produced.

Graph 32. It discloses the consuming amount of fuel oil and gas per ton of cement and clinker production.

Graph 33. It illustrates the consumption of abrasive materials of the ball, segment, and armor in different years.

Graph 34. It shows the consumption of abrasive materials of the ball, segment, and armor in a ton of cement and clinker production in different years.

Graph 35. It presents the consumption of refractory materials, including fire brick.

Graph 36. It demonstrates the consumption of refractory materials of brick and concrete in a ton of cement and clinker production. 
Graph 37. It shows the price of refractory and abrasive materials.

Graph 38. It compares discrepancy between the account of increasing properties, machinery, and equipment with an annual difference of assets. The account of adjustments and transfers of assets shows the untimeliness of the accounting procedure.

Graph 39. It shows the discrepancy between two accounts of increasing properties, machinery, and equipment with the difference of assets items, and the two accounts of the difference of financial year depreciation with the difference of accumulated depreciation.

Graph 40. It compares the book value of properties, machinery, and equipment with their current values.

Graph 4I. It displays the ratio of investment to depreciation.

Graph 42. It reflects the ratio of gross investment to gross capital stock. The mentioned items have been beforehand converted into the present values of that year.

Graph 43. It shows the capital depreciation to the gross capital stock, which has been beforehand converted into the present value of that year.

Graph 44. It displays production value to gross capital stock at constant prices. This figure indicates the capital efficiency during the period under study.

Graph 45. It exhibits the proportion of profit to quantitative, and Rial sells.

Graph 46. It presents the ratio of other revenues and costs, sales and distribution costs, administrative and general cost, the actual cost of sold goods, and sales to profit.

Graph 47. It demonstrates the previous figure in a different way that the profit domain for each year has been presumed as IO0 percent.

Graph 48. The share of different cost components, including wage, mineral raw materials, fuel, electricity, depreciation, packaging materials, consuming materials (abrasive, refractory, and oil) and other items in the short term.

Graph 49. It reveals the percentage of using grinders of raw materials. It should be noted that this figure has been obtained by assuming 20 hours of working per day.

Graph 50. It shows the percentage of using cement grinders. It indicates that grinders are still working below their capacities. In addition, it should be noticed that their working capacity has been calculated based on 20 hours of working per day.

Graph 5I. It presents the percentage of using furnaces.

Graph 52. The summary of the three above figures shows how furnaces and grinders of raw materials and cement have been exploited in the factory. This figure again verifies this fact that the available capacity of the factory has not been fully utilized.

Graph 53. This presents the lost profit due to the disusing total production capacity of the factory. This figure provides information about the amount of lost profit due to not utilizing the factory's total capacity because of various reasons.

Graph 54. It calculates the ratios of profit to gross investment in two states. In the first state, the net profit rate to capital is shown. In the second state, the profit rate when the additional capacity of the factory is utilized is presented.

Graph 55. It examines the sale, profit, and cost of a ton of cement produced. In this figure, revenue and cost of a ton of cement have been provided, and the difference has been assumed as profit.

Graph 56. It shows profit and cost components, which altogether present the sale value of a ton of cement.

Graph 57. It reflects the percentages of cost and profit out of sales for a ton of cement.

Graph 58. It has been tried to find acceptable and stable ratios for depreciation. In Cement Analytical Information Software, three figures have been inserted for depreciation during the concerned years. The first figure is the depreciation of the financial year. The second one is the calculated depreciation of financial year from the actual cost. The last one is the difference obtained from annual accumulated depreciation. In order to find the depreciation trend, the above-mentioned ratios of depreciation to total properties, machinery, and equipment in the same year have been calculated. The trend of these ratios has been illustrated in this figure. Considering various fluctuations in this three depreciation, these three series have been fitted by three second-order polynomial regressions. The achieved fitnesses have been drawn on the same figure.

Graph 59. It shows the estimated actual depreciation in comparison with the booked depreciation. Actual depreciation can be gained by obtaining the present value of capital stock in each year and by considering price indices, the capital stock of the year before, and the calculated ratio of depreciation to capital stock value.

Graph 60. It presents the ratio of actual and booked accumulated depreciation to actual and booked gross capital stock. This figure confirms the unrealistic nature of booked depreciation figures and booked capital value. The depreciation trend is shown by third-order polynomial regression. Regression formulas and some of the required statistics are inserted in this figure, which helps to recheck its significance. 
Graph 6I. It displays actual depreciation of sale, cost, profit (loss) per ton of cement produced by using the obtained figures. This graph is easily comparable with graph 55 .

Graph 62. It reflects the sale, cost, and profit for a ton of cement based on cost components by considering actual depreciation.

Graph 63. It reflects the percentage of sales, costs, and profit for a ton of cement based on cost components by considering actual depreciation.

Graph 64. By showing the trend of cost components of the factory considering actual depreciation, it presents the principal structure and trend of cost developments.

Graph 65. It exhibits the trend of profit (loss) by using sale and long-term cost figures for each ton of cement produced. In this case, the depreciation is book depreciation.

Graph 66. It demonstrates long-term profit (loss) for a ton of cement produced with its cost components.

Graph 67. It shows the trend of sale, profit, and cost values to its components for long term.

Graph 68. It presents the status of long-term profit (loss) for a ton of cement produced by considering actual depreciation.

Graph 69. It displays the trend of components of cost and profit in long-term cost structure by considering actual depreciation.

Graph 70. It reflects the sale value of a ton of cement produced with actual depreciation in the long term and with its components. This graph can be compared with the similar short term graph.

Graph 7I. It examines long-term cost components with actual depreciation.

Graph 72. It has been created according to Leontief efficient production function for cement factory. Optimal usages of production factors in the short term are shown in this graph. Based on this efficient production function, optimal production has been calculated according to the minimum ratio of production factors to the production level in the short term. The difference between the mentioned figure and practical production presents the difference between practical and optimal production. The ratio of this figure to optimal production shows the percentage of the inefficiency of production.

Graph 73. It shows the used level of work in different years in comparison with the optimal need for work.

Graph 74. It exhibits the consumed mineral raw materials compared with their optimal needs.

Graph 75. It shows both practical and optimal uses of fuel.

Graph 76. It indicates the inefficient use of electricity.

Graph 77. It demonstrates the efficient usages of consuming production factors. Consuming materials include abrasive materials, refractory materials, and oils.

Graph 78. It provides the costs due to inefficient usages of production factors. In other words, this figure shows the cost of excess usages of consuming materials, electricity, fuel, consuming raw materials, and workforce, more than their optimal need.

Graph 79. It shows the percentage of the cost of non-optimal usages of each production factor to total costs of non-optimal usages of production factors.

Graph 80. It displays total losses due to inefficiencies of production. These inefficiencies consist of three parts. The first part relates to the opportunity cost due to unproduced cement because of inefficient production. The second part reflects the costs due to inefficient usage of production factors in the short term, and the third part represents the lost profit due to disusing the remained available production capacity (excess of optimal production).

Graph 8I. It shows the ratio of the costs of efficiency to cost.

Graph 82. It reflects the ratios of inefficiency costs to the net and gross capital stock. If practical production is equal to efficient production, the efficiency of the cement factory will be increased up, with the value of these figures.

Graph 83. It reflects one of the characters of accomplishing financial activities at a quick pace in the cement factory. It states that if in each financial year, one month of official administrative works for purchasing can be reduced, how much cost reduction will be achieved. These calculations have been presented in this graph.

Graph 84. It presents the deferred purchase costs as a percentage of profit. In the main trend, one, one, and a half, and two months delays are shown. Each one has been indicated as a percentage of profit.

Graph 85. This provides prices trends, where all are based on the base financial year. The following trends of price indices can be observed; price indices of consumer, wholesaling, wage, forming capital, cement, raw materials, fuel, fuel oil, the calorie of fuel, electricity, and oil.

\section{Cost Reduction Policy (CRP)}

By investigating different cost items in the cement factory, it was clarified that the efficiency required along with costs had not been given emphasis properly. Thus, it seems essential to apply a set of special operational policies in this area. This set of policies is called "Cost Reduction Policy (CRP)" here. The practical recommendation will be in a way that all the main cost 
items need to be examined, and the reason for the inefficiency of each should be explored separately in order to become enabled to reduce the costs related to different items. A solution for this issue can be to determine standards for essential and nonessential costs, which requires expert examination in every single cost item. Categorization of costs into the following components can be a cornerstone to start:

CRP I. Studying personnel costs, including salary, wage, overtime working, employer insurance share, shifts, night working, missions, and other similar costs.

CRP 2. Reducing costs of raw materials, including extraction costs, rights, and duties of mines, explosive materials, and other costs related to extraction of mineral raw materials.

CRP 3. Reducing fuel costs; including purchase prices and costs of fuel oil and gas.

CRP 4. Reducing electricity costs.

CRP 5. Reducing the costs of abrasive materials; including the purchase prices and transportation costs of ball, armor, and segments in grinders and stone crushers.

CRP 6. Reducing the costs of refractory materials; including purchase and transportation costs of fire brick, refractory concrete, and mortar.

CRP 7. Reducing the costs of consuming oils; including their purchase and transportation costs.

CRP 8. Reducing maintenance and depreciation costs.

CRP 9. Examining administrative and general costs, including salaries of staff of office units, guards, costs of building repairs, transportation, water, electricity, training of personnel, etc.

CRP IO. Studying the distribution and sale cost, such as salaries of sale department personnel and other related costs.

CRP II. Financial costs, including interest and charges for loans, purchase of demand notes, bank bills, etc.

CRP 12. Research projects costs.

CRP 13. Bags, sacks, and packaging costs.

CRP I4. Other costs not cited above.

\section{Efficiency Increasing Policy (EIP)}

Considering this fact that production factors can be applied in an optimal way, operational solutions need to be maintained in order to gain the highest efficiency from the utilization of production factors. These are categorized as "Efficiency Increasing Policy (EIP)". Therefore, it is essential to constantly evaluate the indices that can examine the consumption level of each of the following items:

EIP I. The consumption level of mineral raw materials in terms of the following components: soil, limestone, iron ore, gypsum, and pozzolan per ton of production.

EIP 2. The consumption level of electricity per ton of production.

EIP 3. The consumption level of fuel per ton of production, based on the components of gas and fuel oil.

EIP 4. The consumption level of abrasive materials per ton of production, based on components of the ball, segment, and armor.

EIP 5. The consumption level of refractory materials (including fire brick and mortar) per ton of production.

EIP 6. The consumption level of oils per ton of production

EIP 7. The consumption level of bags and packaging materials per ton of production of packed cement.

EIP 8. Practical working level of different production and non-production personnel.

\section{Complementary Policies (CP)}

CP I. The policy of revising management information structure: This policy needs to be designed and implemented along with the two previous policies, i.e., Cost Reduction Policy and Efficiency Increasing Policy, in order to present the method of implementation of those two policies.

CP 2. The policy of increasing workflow speed: Workflow and bureaucratic nature of the factory's activities may lead to many insufficiencies and inefficiencies and also may increase the factory's costs considerably. It seems that creating operational solutions and different policies, such as revising human resource management structure, can be beneficial in resolution of this problem.

CP 3. Planning to reach nominal production capacity: Stoppages in different units of the factory, such as cement grinders and furnaces, can practically lead to a status in which the factory performs under its available nominal capacity. If the factory's management takes special plans for preservation and conservation, these stoppages are likely to be minimized. In other words, the policy of preventing production stoppages is more economical than restarting a stopped 
production line.

\section{References}

Alejandro, C.D. (1974). Labor productivity and other characteristics of the cement plants: an international comparison.

Diewert, W.E. (I97I). An application of the Shepherd duality theorem: a generalized Leontief production function, Journal of political economy, 79, pp. 48I-507.

Clark, K.B. (1980). Unionization and productivity: micro-econometric evidence. The quarterly journal of economics, December, pp. 6I3-639.

Borhani, Ahmad., Saghaeian-Nejad, Hossein., \& Taeb, Abbas. (1996). Estimation of the cost function for the cement industry. Presented in the second international conference on the cement industry, energy, and environment (CIEE), articles: 333-342.

Bidabad, Bijan. (I999). Studying the economic structure of Abyek Cement Factory, Fars \& Khuzestan Cement Co (FKCCO), http://www.bidabad.com/doc/karkhaneh-abyek.pdf

Bidabad, Bijan. (2004). The economic structure and production costs in Abyek Cement Factory. Proceeding of the international conference of cement, for the $50^{\text {th }}$ year of the foundation of Tehran Cement Company, with the cooperation of the the AmirKabir University of Technology and University of Science and Technology, pp. 58I-600, http://www.bidabad.com/doc/abyekfunction.pdf

Bidabad, Bijan. (2004). The methods of economic analysis of Cement Factory. Proceeding of the international conference of cement, for the $50^{\text {th }}$ year of the foundation of Tehran Cement Company, with the cooperation of AmirKabir University of Technology and University of Science and Technology, the second volume, pp. 503-53I, http://www.bidabad.com/doc/abyekfunction.pdf

Bidabad, Bijan., 'Quantitative effects of joining WTO on Iran industrial sector', I994.

Bidabad, Bijan., 'Designing an econometric model to measure the changes in imports and exports of the industry sector ', Chapter 5, 1994.

Bidabad, Bijan; Mahshid Sherafati, Roohollah Mohammadi. Operational and Efficient Production Functions (Measuring Efficiency in Abyek Cement Factory). International Conference on Business Strategy and Social Sciences (ICBSSS), Asian Economic and Social Society (AESS), Faculty of Technology Management and Business, Universiti Tun Hussein Onn Malaysia, and Pak Publishing Group. 16-I7 August 2014, Kuala Lumpur, Malaysia. http://www.bidabad.com/doc/abyekanalysis-short-en.pdf

Bidabad, Bijan, Nahid Kalbasi Anaraki. Effects of Iran's WTO accession on the cement industry. Effects of Iran's WTO accession on the cement industry. With co-operation of Nahid Kalbasi Anaraki. European Cement Conference 2004 proceedings, 4th conference and exhibition for the trends, the environment, emissions trading, markets, production and processing technology of cement in Europe, I5-I6 March 2004, Barcelona, Spain, pp.3.I-3.8, Pro Publications International Ltd. http://www.bidabad.com/doc/cement-wto-barcelona.pdf

Thuesen, G.J., \& Fabrycky, W.J. (I993). Engineering economy, Prentice-hall, $8^{\text {th }}$ ed.

Forsund, F.R., \& Hjalmarsson, L. (I983). Technical progress and structural change in the Swedish cement industry I955I979, Econometrica, vol. 5I, no.5, September.

Johansen, L. (1972). Production functions, Amsterdam, North-Holland Publishing Co.

Savabi-asl, Farhad., Bidabad, Bijan., \& Shahrestani. (1993). Estimation of Iran macro-investment function by considering different production functions, Master of science in economics thesis, Islamic Azad University (Tehran Branch).

Khayyambashi, Bijan. (1996). Production function and its econometrics with regard to the cement industry in Iran, Proceeding of the second international conference on cement industry, energy, and environment (CIEE), pp: 343-352.

Taeb, Abbas. \& Ali-Ahmadi, Alireza. (1996). Actual cost of cement production. Proceeding of the second international conference on cement industry, energy, and environment (CIEE), pp: 323-332.

Azizian, Mohammad-Reza. (1984). Cement, Ketab-sara Publications.

\section{Copyrights}

Copyright for this article is retained by the author(s), with first publication rights granted to the journal. This is an open-access article distributed under the terms and conditions of the Creative Commons Attribution license (http://creativecommons.org/licenses/by/4.0/). 